\title{
(4th) Carbon-Supported Palladium-Cobalt-Noble Metal (Au, Ag, Pt)
Nanocatalysts as Methanol Tolerant Oxygen-Reduction
Cathode Materials in DMFCs
}

\author{
J. Mathiyarasu ${ }^{\mathrm{z}}$ and K. L. N. Phani
}

Electrodics and Electrocatalysis Division, Central Electrochemical Research Institute,

Karaikudi-630 006 India

The carbon-supported nanoparticles of $\mathrm{Pd}-\mathrm{Co}-\mathrm{M}(\mathrm{M}=\mathrm{Pt}, \mathrm{Au}, \mathrm{Ag})$ catalysts for direct methanol fuel cells (DMFCs) in a ratio of (70:20:10) were prepared through reverse microemulsion method. The X-ray diffraction (XRD) analysis showed well-defined reflections corresponding to a face centered cubic phase of palladium. From transmission electron microscopy analysis, the particle size after heat-treatment at $500^{\circ} \mathrm{C}$ was found to be approximately $20 \mathrm{~nm}$, which was also confirmed by XRD analysis. Polarization data indicated $\mathrm{Pd}-\mathrm{Co}-\mathrm{Pt}$ to have better oxygen reduction reaction (ORR) activity than the other combinations with $\mathrm{Ag}$ and $\mathrm{Au}$, in terms of shift in onset potential to a positive value of more than $100 \mathrm{mV}$ and increased reduction current. The ORR kinetics on $\mathrm{Pd}-\mathrm{Co}-\mathrm{Pt}$ was analyzed by using rotating disk electrode to follow a 4 electron pathway, the order of the reaction being unity. The peroxide formation estimated from the rotating ring disk electrode measurements was found to be a negligibly small amount of $1.1 \%$. An additional advantage observed with Pd-Co-Pt was its high methanol tolerance and ORR activity nearly equal to Pt. (C) 2007 The Electrochemical Society. [DOI: 10.1149/1.2772417] All rights reserved.

Manuscript submitted March 30, 2007; revised manuscript received June 23, 2007. Available electronically August $30,2007$.

The major problem which concerns the developments in the direct methanol fuel cells (DMFCs) is the crossover of methanol through the polymer electrolyte membrane to the cathode compartment. ${ }^{1}$ This results in establishment of mixed potentials and depolarization of cathode potential, reduction of cell power and conversion losses due to fuel loss. ${ }^{2-9}$ The simultaneous reduction of oxygen and suppression of fuel oxidation at the cathode requires electrode materials selective to oxygen reduction reaction (ORR) and further the catalyst should be tolerant to methanol.

Therefore efforts are under way in developing new generation electrocatalysts to address these problems, by examining the requirements for selective ORR and improvements in the electrocatalytic characteristics. Platinum is the best known cathode catalyst, which has not been replaced by other materials so far. But the problem with the Pt catalyst is the high affinity towards adsorption of methanol on its surface. This leads to the catastrophic loss in the performance of DMFCs. Hence, Pt catalyst materials are developed by suitably alloying with secondary elements and studies have shown that platinum-based binary alloyed electrocatalysts such as $\mathrm{PtFe}, \mathrm{PtCo}, \mathrm{PtNi}, \mathrm{PtBi}$, and $\mathrm{PtCr}$ exhibit a higher catalytic activity for ORR in acid electrolytes than pure platinum. ${ }^{10-22}$ These catalysts have already shown nearly the same activity for the ORR in the absence as well as in the presence of methanol.

Recent research has shown the practicality of using nonplatinum metal alloys for ORR with resistance to methanol oxidation. Several nonplatinum electrocatalysts are reported for their adequate oxygen reduction activity to be considered as potential catalysts in commercial fuel cell applications. Nonprecious catalysts such as metal phthalocyanines, ${ }^{23,24}$ transition metalloporphyrins, ${ }^{25,26}$ transition metal sulfide ${ }^{27}$ and ruthenium alloys, ${ }^{28,29}$ show a high selectivity for ORR in acid medium containing methanol in contrast to platinum. Even though they show high methanol tolerance, their activity for ORR in a methanol free electrolyte is significantly lower than that of the conventional platinum electrocatalyst and their long-term operational stability at higher temperatures is very poor.

In this sense, palladium-based plurimetallic catalysts appear cheaper compared to the conventional Pt-based ORR catalyst. Palladium alloys with $\mathrm{Co}, \mathrm{Cr}, \mathrm{Fe}, \mathrm{Mo}, \mathrm{Ti}, \mathrm{Au}$, and $\mathrm{Ni}$ have shown catalytic activity close to that of platinum, giving scope for replacing the latter. ${ }^{30-42}$ These nonprecious metal catalysts present a viable alternative to noble-metal catalysts provided they demonstrate substantial activity and long-term operational stability.

Though non-noble metal alloy catalysts are explored as methanol

żE-mail: al_mathi@yahoo.com tolerant ORR catalysts, their activity towards ORR is still lower than $\mathrm{Pt}-\mathrm{C}$ as reported in the literature. ${ }^{33,36}$ Further, the nonprecious metal catalysts do not match the performance of conventional platinum in the sense of low ORR kinetics and stability in the acidic environment and hence it is very difficult to avoid the loading of the precise metal in the cathode. Recently, several groups have published results obtained for $\mathrm{Pd}-\mathrm{Co} / \mathrm{C}$ as an electrocatalyst for oxygen reduction reaction. ${ }^{35-42}$ Although the hydrodynamic voltammograms presented by Shao et al. ${ }^{42}$ for $\mathrm{Pd}-\mathrm{Co} / \mathrm{C}$ vouch for its suitability as a substitute for $\mathrm{Pt} / \mathrm{C}$, the data subsequently published by others do not, for example, Zhang and Lee ${ }^{39}$ and as observed in the present investigations. Shao et al. and Zhang et al. have also explored the introduction of monolayer levels of platinum on nonplatinum alloys for increasing the efficiency ${ }^{42,43}$ and demonstrated improvements using these catalysts. However, it is possible for these monolayer-based catalysts to undergo fast surface changes that can affect the catalytic activity. Hence, it would be interesting to investigate systems where all the alloy elements and the materials that contribute to the catalyst stability exist in unison. Though proved efficient as a nonprecious alternative to platinum, $\mathrm{Pd}-\mathrm{Co} / \mathrm{C}$ still requires small amounts of stabilizers like $\mathrm{Au}$, as reported by Fernandez et al. ${ }^{30,36}$ for its stable performance. In this work, with an intent to take advantage of the beneficial effects of such additions, we examined $\mathrm{Au}, \mathrm{Ag}$, and $\mathrm{Pt}$ as an integral part of the catalyst rather than as monolayers. Pd-Co-M $(\mathrm{M}=\mathrm{Pt}, \mathrm{Au}, \mathrm{Ag})$ catalysts of various compositions were synthesized using reverse microemulsion technique. The composition and structure of the catalyst and electrocatalytic activity towards ORR were studied with and without methanol.

\section{Experimental}

Preparation of carbon supported nanosized Pd-Co alloy catalysts. - The carbon supported Pd based catalysts (referred to as $\mathrm{Pd}-\mathrm{Co}-\mathrm{M} / \mathrm{C})$ in a ratio of 70:20:10 with a metal(s) loading of $20 \mathrm{wt} \%$ were prepared by a reverse microemulsion method ${ }^{36}$ using sodium dioctylsulfosuccinate (AOT) as the surfactant and heptane as the oil phase. Briefly, microemulsion I was prepared by mixing required amounts of ammonium hexachloropalladate, cobalt nitrate, dihydrogen tetrachloroaurate, AOT, deionized water, and heptane under constant stirring followed by ultrasonication for $20 \mathrm{~min}$. Microemulsion II was prepared by mixing sodium borohydride, AOT, deionized water, and heptane under constant stirring followed by ultrasonication for $20 \mathrm{~min}$. In both the microemulsions, the molar ratio of water to AOT was kept at 10:1. Microemulsion I and microemulsion II were mixed together and ultrasonicated for $2 \mathrm{~h}$. After that, an appropriate amount of carbon (Vulcan XC 72R) was added to the mixture to give a metal(s):C weight ratio of $20: 80$. The result- 


\begin{tabular}{|c|c|c|c|c|c|c|}
\hline Catalyst & $\begin{array}{c}\text { EDX } \\
\text { composition } \\
(\%)\end{array}$ & $\begin{array}{c}\text { Lattice } \\
\text { parameter } \\
a_{\mathrm{fct}} \\
(\mathrm{nm})\end{array}$ & $\begin{array}{l}\text { XRD } \\
\text { Particle } \\
\text { size } \\
(\mathrm{nm})\end{array}$ & $\begin{array}{c}\text { TEM } \\
\text { Particle } \\
\text { size } \\
(\mathrm{nm})\end{array}$ & $\begin{array}{l}\text { Roughness } \\
\text { factor by TEM } \\
\left(\mathrm{cm}^{2} \mathrm{~cm}^{-2}\right)\end{array}$ & $\begin{array}{c}\text { Specific } \\
\text { electrochemical } \\
\text { area } \\
\left(\mathrm{m}^{2} / \mathrm{g}\right)\end{array}$ \\
\hline $\mathrm{Pd}-\mathrm{Co}$ & 89:11 & 0.3894 & 33.2 & $29 \pm 2$ & 194 & 15 \\
\hline $\mathrm{Pd}-\mathrm{Co}-\mathrm{Au}$ & $79: 12: 9$ & 0.3877 & 22.1 & $23 \pm 2$ & 212 & 23 \\
\hline $\mathrm{Pd}-\mathrm{Co}-\mathrm{Ag}$ & $80: 11: 9$ & 0.3879 & 24.9 & $26 \pm 2$ & 200 & 116 \\
\hline $\mathrm{Pd}-\mathrm{Co}-\mathrm{Pt}$ & $80: 12: 8$ & 0.3875 & 19.9 & $18 \pm 2$ & 269 & 100 \\
\hline
\end{tabular}

ant slurry was kept under constant stirring for $2 \mathrm{~h}$, filtered, washed copiously with acetone and deionized water, and dried in an air oven for $2 \mathrm{~h}$. In order to study the effect of heat-treatment on the catalytic activity, the samples thus synthesized were heated at 500, 750, and $900{ }^{\circ} \mathrm{C}$ in a flowing mixture of $10 \% \mathrm{H}_{2}-90 \% \mathrm{Ar}$ for $1 \mathrm{~h}$ followed by cooling to room temperature at a rate of $5^{\circ} \mathrm{C} / \mathrm{min}$.

Heat-treatment of the catalyst is crucial for the formation of an alloy. When the heat-treatment temperature was lower than $300^{\circ} \mathrm{C}$, a mixture of pure Pd phase and an alloy phase was found from X-ray diffraction (XRD) determinations. ${ }^{39}$ With the increase in alloying temperature, we found a slight increase in the particle size and a slight decrease in the lattice parameter. A suitable alloying temperature was $\sim 500^{\circ} \mathrm{C}$. Such an alloying temperature is significantly lower than that given in the previously published reports, ${ }^{34,35}$ which could be beneficial to the formation of small alloy particles with a narrow particle size distribution. After heat-treatment, the sample was washed with water until no chloride ions were detected and then dried under nitrogen at about $130^{\circ} \mathrm{C}$.

XRD measurements of $\mathrm{Pd}-\mathrm{Co}$ carbon-supported catalysts were carried out on a Philips Pananalytical X-ray diffractometer using $\mathrm{Cu}$ $\mathrm{K} \alpha$ radiation $(\lambda=0.15406 \mathrm{~nm})$. The XRD spectra were obtained using high resolution in the step-scanning mode with a narrow receiving slit $\left(0.5^{\circ}\right)$ with a counting time of $15 \mathrm{~s}$ per $0.1^{\circ}$. Scans were recorded in the $2 \theta$ range of $15-90^{\circ}$. The identification of the phases was made by referring to the Joint Committee on Powder Diffraction Standards (JCPDS) International Center for Diffraction Data database. In order to estimate the particle size from XRD, Scherrer's equation was used. For this purpose, the (220) peak of the Pd facecentered-cubic (fcc)/fct structure around $2 \theta=68.8^{\circ}$ was selected.

Transmission electron microscopy (TEM) analysis was carried out using TEM microscope JEOL, JEM 3010, URP, operating at $300 \mathrm{kV}$ and having a resolution of $0.17 \mathrm{~nm}$. The samples for the TEM characterization were prepared as follows: a carbon film was deposited onto a mica sheet that was placed onto the $\mathrm{Cu}$ grids (300 mesh and $3 \mathrm{~mm}$ diameter). The material to be examined was dispersed in water by sonication, placed onto the carbon film and left to dry. The average particle size was calculated using about 300 particles.

The performance of $\mathrm{Pd}-\mathrm{Co}-\mathrm{M}(\mathrm{M}=\mathrm{Pt}, \mathrm{Au}, \mathrm{Ag})$ alloy catalysts and a commercial Pt/C (20 wt \%, E-TEK) catalyst for the ORR was evaluated preliminarily with a half-cell configuration based on the linear scan voltammogram (LSV) measurements. Ten milligrams of catalysts, $0.5 \mathrm{~mL}$ of Nafion solution (5 wt \%, Aldrich) and $2.5 \mathrm{~mL}$ of water were mixed ultrasonically. A measured volume $(3 / 10 \mu \mathrm{L})$ of this ink was transferred via a syringe onto a freshly polished glassy carbon disk $(3 / 6 \mathrm{~mm}$ in diameter). After the solvents were evaporated overnight at room temperature, the prepared electrode served as the working electrode.

All chemicals used were of analytical grade. All the solutions were prepared with ultrapure water (MilliQ, Millipore). Electrochemical measurements were performed using a BAS 100B or Autolab PGSTAT 30 potentiostat/galvanostat [for rotating ring disk electrode (RRDE) experiments where the equipment is coupled BIPOT module] and a conventional three-electrode electrochemical cell. The counter electrode was a glassy carbon plate and a mercury/ mercurous sulfate electrode served as the reference electrode. How- ever, all potentials are referred to the mercury-mercurous sulfate electrode (MSE). The electrolyte used for half-cell measurements was $0.5 \mathrm{M} \mathrm{H}_{2} \mathrm{SO}_{4}$ or $0.5 \mathrm{M} \mathrm{H}_{2} \mathrm{SO}_{4}+0.5 \mathrm{M} \mathrm{CH}_{3} \mathrm{OH}$. Due to a slight contamination from the Nafion solution, the porous electrodes were cycled at $50 \mathrm{mV} / \mathrm{s}$ between -0.65 and $0.5 \mathrm{~V}$ vs MSE until reproducible cyclic voltammograms were obtained, prior to any LSV measurements. The upper potential was set to $0.5 \mathrm{~V}$ vs MSE so that changes in the particle size and the surface composition of the catalysts could be avoided. Note that no marked changes in the shape and size of the CVs were observed throughout the electrochemical measurements. Also, the Pt real surface area of all the catalysts remained almost constant, indicating that the catalysts are stable under the experimental conditions. The real surface areas of Pt based catalysts obtained are given in Table I. The electrochemical activity for the ORR was measured with the rotating ring disk electrode (RRDE) technique using an interchangeable ring-disk electrode setup coupled with a rotation controller (Pine Instruments). High purity nitrogen and oxygen were used for deaeration and oxygenation of the solutions. During the measurements, a blanket of nitrogen or oxygen was maintained above the electrolyte surface. Unless stated otherwise, all half-cell tests were performed at a temperature of $25 \pm 1^{\circ} \mathrm{C}$.

\section{Results and Discussion}

Figure 1 shows XRD patterns of the carbon-supported Pd-Co catalysts with a metal loading of $20 \mathrm{wt} \%$ and the addition of noble

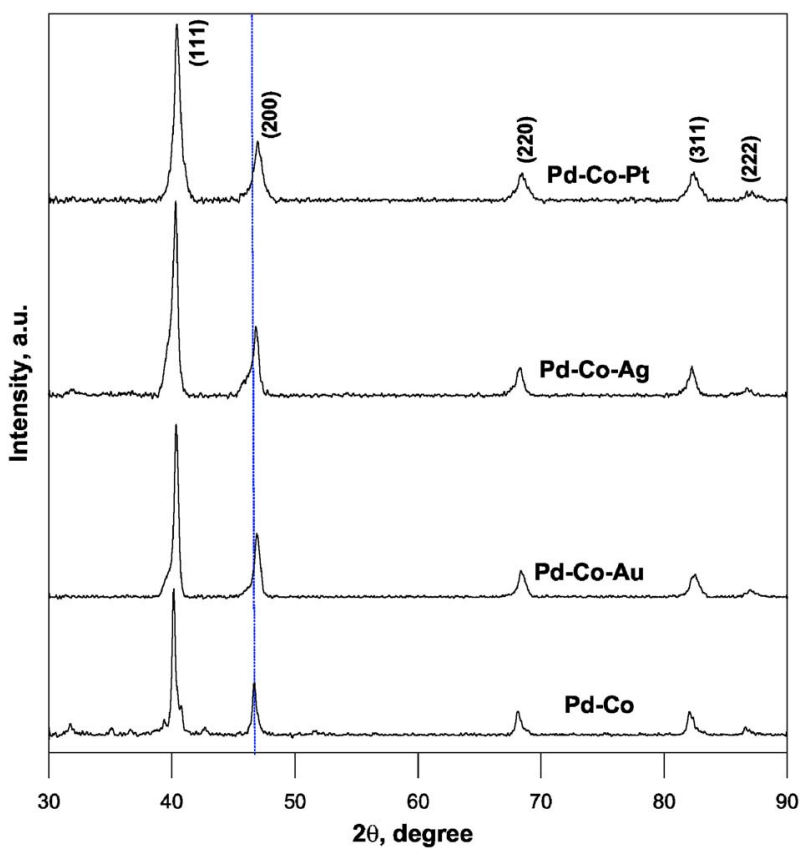

Figure 1. (Color online) Comparison of XRD patterns of carbon supported $\mathrm{Pd}-\mathrm{Co}-\mathrm{X}$ alloy catalysts heat-treated at $500^{\circ} \mathrm{C}$ and the dashed line represents the standard (200) reflection of Pd. 

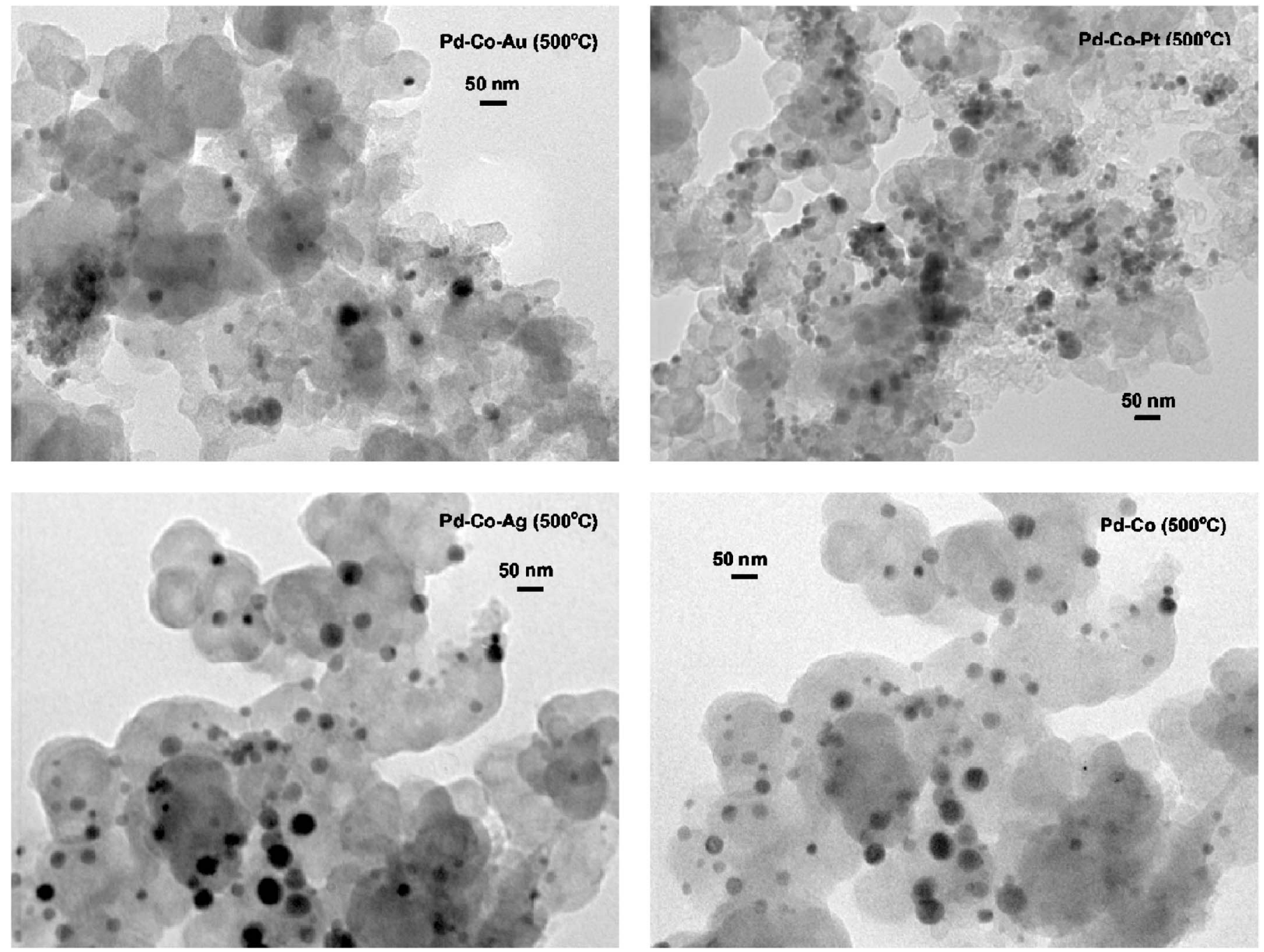

Figure 2. TEM images of the $\mathrm{Pd}-\mathrm{Co}-\mathrm{X} / \mathrm{C}(\mathrm{X}=\mathrm{Ag}, \mathrm{Au}, \mathrm{Pt})$ alloy catalysts with $20 \mathrm{wt} \%$ metal loading.

metal loading such as $\mathrm{Au}, \mathrm{Pt}$, and $\mathrm{Ag}$ at a ratio of 70:20:10 atomic ratios, which is heat treated at $500^{\circ} \mathrm{C}$. From the figure, it is observed that all the XRD patterns exhibit five main characteristics peaks of the fcc crystalline Pd (JCPDS Card 00-005-0681), namely the planes (111), (200), (220), (311), and (222) demonstrating that all the alloy catalysts mainly resemble the single-phase disordered structure (solid solution). The five diffraction peaks in the $\mathrm{Pd}-\mathrm{Co}-\mathrm{X}$ alloy catalysts are shifted to higher $2 \theta$ values compared to those of $\mathrm{Pd}-\mathrm{Co}$ upon heat-treatment suggesting incorporation of $\mathrm{Co}$ and a smaller amount of the noble metal into the Pd lattice. The reflections correspond to only a single fcc phase suggestive of formation of a ternary $\mathrm{Pd}-\mathrm{Co}-\mathrm{X}$ alloy phase. The absence of peaks for either Co or X or their oxides indicates that the alloy constituents were thoroughly mixed in the crystal system. The addition of a noble metal at a lower concentration led to a decrease in the lattice dimension, for example, $0.3875 \mathrm{~nm}$ in the case of $\mathrm{Pd}-\mathrm{Co}-\mathrm{Pt}$ resulting in a reduction in the Pd-Pd bond distance.

Figure 2 shows the TEM images of the carbon supported Pd-Co alloys with the added noble metal. From the images, it can be concluded that all the catalysts are well dispersed on the carbon surface with a narrow particle size distribution. It is also observed that the average particle size is slightly higher than the untreated one (figure not shown) and the heat-treatment appears to favor agglomeration as reported earlier. ${ }^{35,39}$ It is also noted that a few larger sized particles $(>40 \mathrm{~nm})$ are also observed, which are formed due to aggregation of the particles at higher temperatures. The particle sizes obtained from the images are in agreement with those calculated from the XRD (200) peaks using Scherrer equation (Table I). The surface area $(S S A)$ of the metal particles was calculated using the equation

$$
S S A\left(\mathrm{~cm}^{2} / \mathrm{mg}\right)=6 \times 10^{-4} / \rho d
$$

where $d$ is the mean metal particle size in nm (from TEM results) and $\rho$ is the density of Pd $\left(12 \mathrm{~g} / \mathrm{cm}^{3}\right)$ or the alloy $\left(11.66 \mathrm{~g} / \mathrm{cm}^{3}\right.$ for $\mathrm{Pd} / \mathrm{Co}$ ). Further, the roughness factor is calculated by multiplying the $S S A$ with the Pd-Co alloy loading in the electrode $\left(1 \mathrm{mg} / \mathrm{cm}^{2}\right)$.

Figure 3 shows the cyclic voltammetric curves of $\mathrm{Pd}-\mathrm{Co}$ alloys that are heat-treated at $500^{\circ} \mathrm{C}$. The current densities in the hydrogen adsorption/desorption and oxide formation-reduction regions of $\mathrm{Pd}-\mathrm{Co}-\mathrm{X}$ are larger than those seen for $\mathrm{Pd}-\mathrm{Co}$ alone. For the ternary alloy the large peak area might be due to desorption of hydrogen on the ternary alloy catalyst surface. The specific electrochemical areas of the nanoparticles, calculated from the $H_{\text {upd }}$ charge (assuming that the alloy ingredients have no effect on the hydrogen adsorption/desorption behavior) are listed in Table I. Larger electrochemical areas are observed for $\mathrm{Pd}-\mathrm{Co}-\mathrm{Pt}$ alloys than that of $\mathrm{Pd}-\mathrm{Co}$, indicating that rough surfaces are formed during alloying.

Oxygen reduction reaction on carbon supported $\mathrm{Pd}-\mathrm{Co}-\mathrm{M}$ alloy nanoparticles.-Figure 4 shows the ORR polarization curves for carbon supported $\mathrm{Pd}-\mathrm{Co}, \mathrm{Pd}-\mathrm{Co}-\mathrm{Pt}, \mathrm{Pd}-\mathrm{Co}-\mathrm{Au}, \mathrm{Pd}-\mathrm{Co}-\mathrm{Ag}$, and $\mathrm{Pt}$ catalysts in oxygen saturated solution of $0.5 \mathrm{M}$ sulfuric acid obtained using a rotating ring disk electrode at $1600 \mathrm{rpm}$. The curve of 


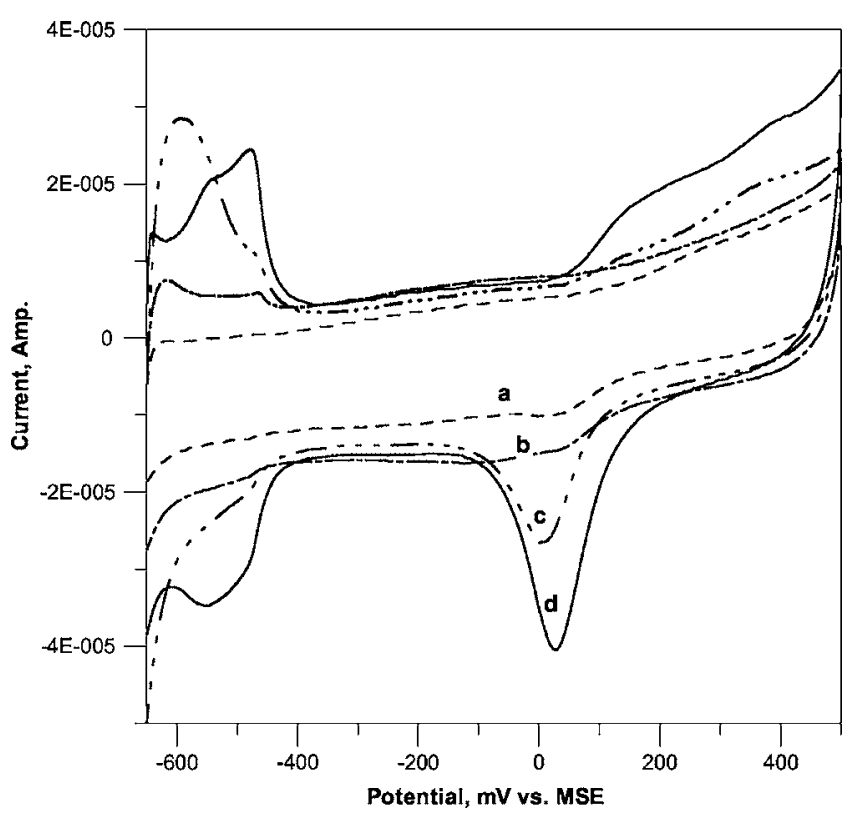

Figure 3. Cyclic voltammetric behavior of carbon supported (a) $\mathrm{Pd}-\mathrm{Co} / \mathrm{C}$, (b) $\mathrm{Pd}-\mathrm{Co}-\mathrm{Au} / \mathrm{C}$, (c) $\mathrm{Pd}-\mathrm{Co}-\mathrm{Ag} / \mathrm{C}$ and (d) $\mathrm{Pd}-\mathrm{Co}-\mathrm{Pt} / \mathrm{C}$, in $0.5 \mathrm{M}$ sulfuric acid at $100 \mathrm{mV} / \mathrm{s}$ scan rate.

Pd-Co-Pt shows an approx. $100 \mathrm{mV}$ shift to more positive potentials compared with other Pd alloy systems. When compared to commercial $\mathrm{Pt} / \mathrm{C}$, there is not much difference in the half-wave potential value. The activity of $\mathrm{Pd}-\mathrm{Co}-\mathrm{Pt} / \mathrm{C}$ is higher than that of the other alloy compositions and equal to the commercial $\mathrm{Pt} / \mathrm{C}$ electrocatalyst (20\% loading on carbon). The respective half-wave potentials are $10 \mathrm{mV}$ and $-40 \mathrm{mV}$ vs MSE. The ORR onset potentials for the other alloys are similar. According to Bard's work, the addition of $10 \% \mathrm{Au}$ allowed them to increase the stability of the catalyst with high electrocatalytic activity. However, in our studies we find from

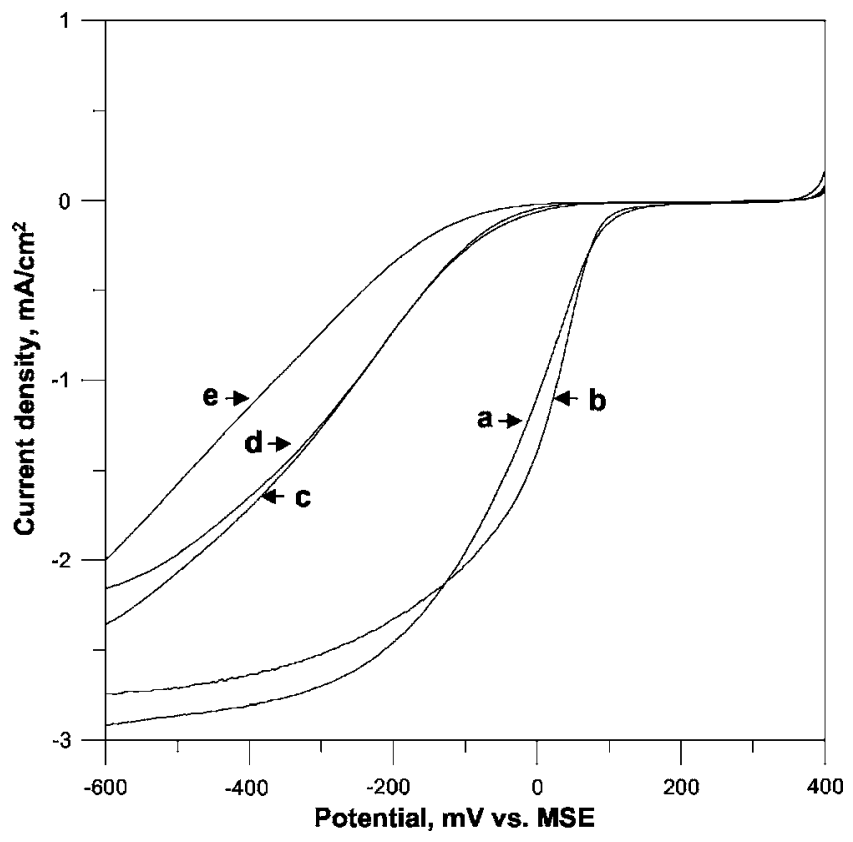

Figure 4. Comparison of polarization curves for the ORR on carbon supported (a) $\mathrm{Pt} / \mathrm{C}$ alloy, (b) $\mathrm{Pd}-\mathrm{Co}-\mathrm{Pt} / \mathrm{C}$, (c) $\mathrm{Pd}-\mathrm{Co}-\mathrm{Ag} / \mathrm{C}$, (d) $\mathrm{Pd}-\mathrm{Co} / \mathrm{C}$, and (e) $\mathrm{Pd}-\mathrm{Co}-\mathrm{Au} / \mathrm{C}$ catalyst in $0.5 \mathrm{M}$ sulfuric acid solution, scan rate $5 \mathrm{mV} / \mathrm{s}$; rotation rate $1600 \mathrm{rpm}$; room temperature.
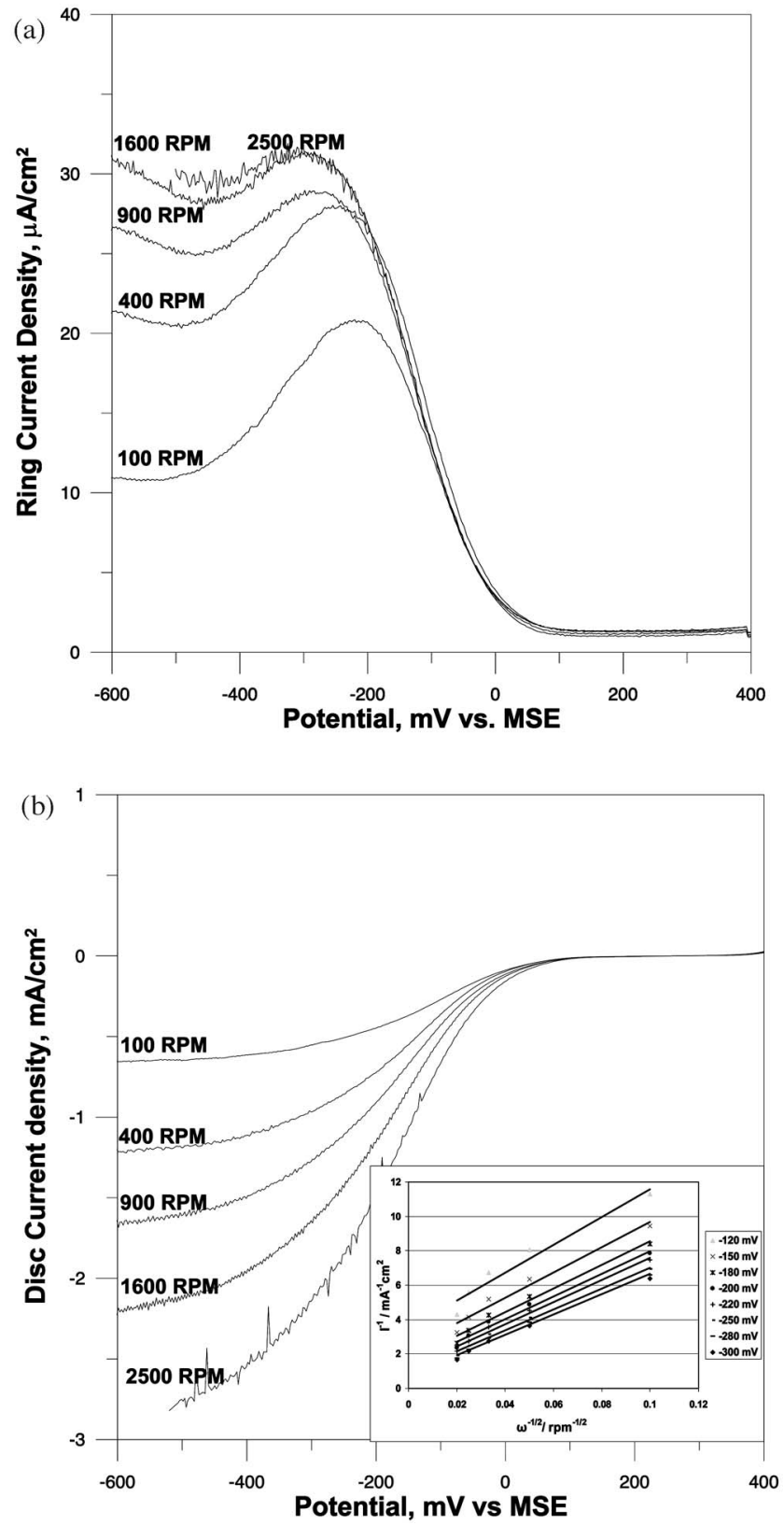

Figure 5. Rotating disk-ring electrode measurements of the ORR obtained with the $\mathrm{Pd}-\mathrm{Co}-\mathrm{Pt} / \mathrm{C}$ nanoparticle film electrode in a $0.5 \mathrm{M} \mathrm{H}_{2} \mathrm{SO}_{4}$ solution. The ring and disk areas are 0.037 and $0.164 \mathrm{~cm}^{-2}$, respectively; scan rate $5 \mathrm{mV} \mathrm{s}^{-1}$. Ring potential is $1.27 \mathrm{~V}$, collection efficiency $24 \%$.

the polarization curves that the combination with Au does not show any improvement while our platinum addition in the place of $\mathrm{Au}$ does improve the performance.

For a quantitative evaluation of ORR kinetics catalyzed by the $\mathrm{Pd}-\mathrm{Co}-\mathrm{Pt} / \mathrm{C}$ alloy, current-potential curves at different rates of rotation were recorded at a potential scan rate of $5 \mathrm{mV} \mathrm{s}^{-1}$ using a rotating glassy carbon disk (coated with $\mathrm{Pd}-\mathrm{Co}-\mathrm{Pt} / \mathrm{C}$ )-platinum ring electrode (RRDE). Figure 5a shows typical current-potential curves obtained in an oxygen-saturated $0.5 \mathrm{M} \mathrm{H}_{2} \mathrm{SO}_{4}$ solution at $25^{\circ} \mathrm{C}$. The limiting currents can be observed as the electrode potential becomes more negative (i.e., $-0.2 \mathrm{~V}$ ), indicating that the diffusion process becomes the dominant step in the electrocatalytic reaction.

In the case of thin films of supported catalyst in Nafion the Koutecky-Levich (K-L) plots can be considered for the kinetic measurements and from the K-L equation 


$$
1 / i=1 / i_{k}+B / \omega^{1 / 2}
$$

where $i$ is the measured current density, $i_{k}$ is the kinetic current density, $B$ is a constant, and $\omega$ is the rotation rate. The linearity and parallelism of the K-L plot (Fig. 5b, inset) confirm that the electrochemical reaction follows the first-order kinetics with respect to the diffusing species, i.e., molecular oxygen. The intercept value, $1 / i$ at $1 / \omega^{1 / 2}=0$ gives the kinetic current values for ORR. From the slopes of the K-L plots, i.e., the constant $B$, the number of electrons exchanged in the reduction of oxygen can be obtained. An experimental value of $B=0.05 \mathrm{~mA} / \mathrm{rpm}$, evaluated from Fig. 5 (K-L plot), agrees well with the calculated value of $B^{\prime}=0.055 \mathrm{~mA} / \mathrm{rpm}$. The calculation was performed for the 4-electron reduction using the published data for oxygen solubility $\left(1.26 \times 10^{-3} \mathrm{~mol} / \mathrm{L}\right)$, the solution's kinematic viscosity $\left(1.009 \times 10^{-2} \mathrm{~cm}^{2} \mathrm{~s}^{-1}\right)$ and oxygen diffusivity $\left(1.93 \times 10^{-5} \mathrm{~cm}^{2} \mathrm{~s}^{-1}\right){ }^{43}$ Reasonably good agreement between the experimental value and the calculated values with $n=4 \mathrm{e}$ suggests a multielectron charge transfer in the oxygenreduction reaction.

There is no appreciable ring current observed in the kinetic region and whatever the ring currents observed are only from the diffusion control region. The percentage of peroxide formation was calculated at a potential of $-300 \mathrm{mV}$ vs MSE using the following equation

$$
\% \mathrm{H}_{2} \mathrm{O}_{2}=2 I_{R} / N / I_{D}+\left(I_{R} / N\right)
$$

where $I_{D}$ and $I_{R}$ are the disk and ring currents, respectively, and $N$ is the collection efficiency of the RRDE. From the above equation, the amount of peroxide formation at this potential was found to be $1.1 \%$, which is considered to be negligible. Recently, $4.1 \%$ of peroxide generation on the $\mathrm{Pd}_{2} \mathrm{Co} / \mathrm{C}$ nanaoparticle film was reported at a potential of $0.4 \mathrm{~V}$ vs reversible hydrogen electrode $(-0.28 \mathrm{~V}$ vs MSE) by the Shao group. ${ }^{42}$

In order to investigate the activity of the $\mathrm{Pd}-\mathrm{Co}-\mathrm{Pt}$ nanoparticles for ORR under methanol crossover conditions, the rotating disk electrode (RDE) technique was used in oxygen-saturated solutions with and without methanol. Figure 6 shows the voltammetric behavior of $\mathrm{Pt} / \mathrm{C}$ and $\mathrm{Pd}-\mathrm{Co}-\mathrm{Pt} / \mathrm{C}$ towards ORR in the presence and absence of methanol. The presence of $0.5 \mathrm{M}$ methanol in an acidic solution causes a negative shift of $\sim 50 \mathrm{mV}$ in the half-wave potential. From the above, it can be noted that the ORR activity of $\mathrm{Pd}-\mathrm{Co}-\mathrm{Pt}$ alloy is comparable with the performance of the commercial $\mathrm{Pt} / \mathrm{C}$. Figure 7 shows the linear scan voltammograms of the methanol oxidation on $\mathrm{Pd}-\mathrm{Co}$ alloy catalyst and the $\mathrm{Pt} / \mathrm{C}$ electrocatalyst in $0.5 \mathrm{M} \mathrm{H}_{2} \mathrm{SO}_{4}+0.5 \mathrm{M} \mathrm{CH}_{3} \mathrm{OH}$ solution. It can be seen that the current densities of the methanol oxidation reaction on $\mathrm{Pd}-\mathrm{Co}-\mathrm{X}$ alloy catalysts $(\mathrm{X}=\mathrm{Au}, \mathrm{Ag}, \mathrm{Pt})$ diminish to values much lower than on $\mathrm{Pt} / \mathrm{C}$ catalyst. It is of interest to note that the voltammetric currents for methanol oxidation are much lower than those observed at $\mathrm{Pt} / \mathrm{C}$ and the onset of oxidation current rise occurs at more positive potentials, indicating lowered MOR activity of the $\mathrm{Pd}-\mathrm{Co}-\mathrm{Pt}$ alloy catalyst. It is conjectured that the amount of platinum in the alloy catalyst will not be amenable to appreciable levels of "platinum skin" formation and in turn produce PtOH in quantities much lower (as in the case of platinum monolayers studied by Zhang's group ${ }^{44}$ ) than what is required for MOR to take place efficiently. Pd-Co, being very catalytically active towards ORR, this small extent of PtOH formation will not affect the reaction. Using theoretical calculations, Wang and Balbuena ${ }^{45}$ showed that this bimetallic system thermodynamically has performance similar to Pt to catalyze ORR. However, in the presence of methanol, a cathodic shift of $\sim 110 \mathrm{mV}$ in the half-wave potential of ORR is observed (Fig. 6) that might arise possibly from partial site blocking effects of organic adsorption. In addition, the current density values remain unaffected in the presence of methanol. Both CV and RDE measurements of Pd-Co-Pt nanoparticles in methanol solution indicate that MOR on this catalyst is very slow. With this "trade-off," the $\mathrm{Pd}-\mathrm{Co}-\mathrm{Pt}$ system is well behaved towards oxygen reduction and is methanol tolerant, considering the total loss of activity of $\mathrm{Pt} / \mathrm{C}$.
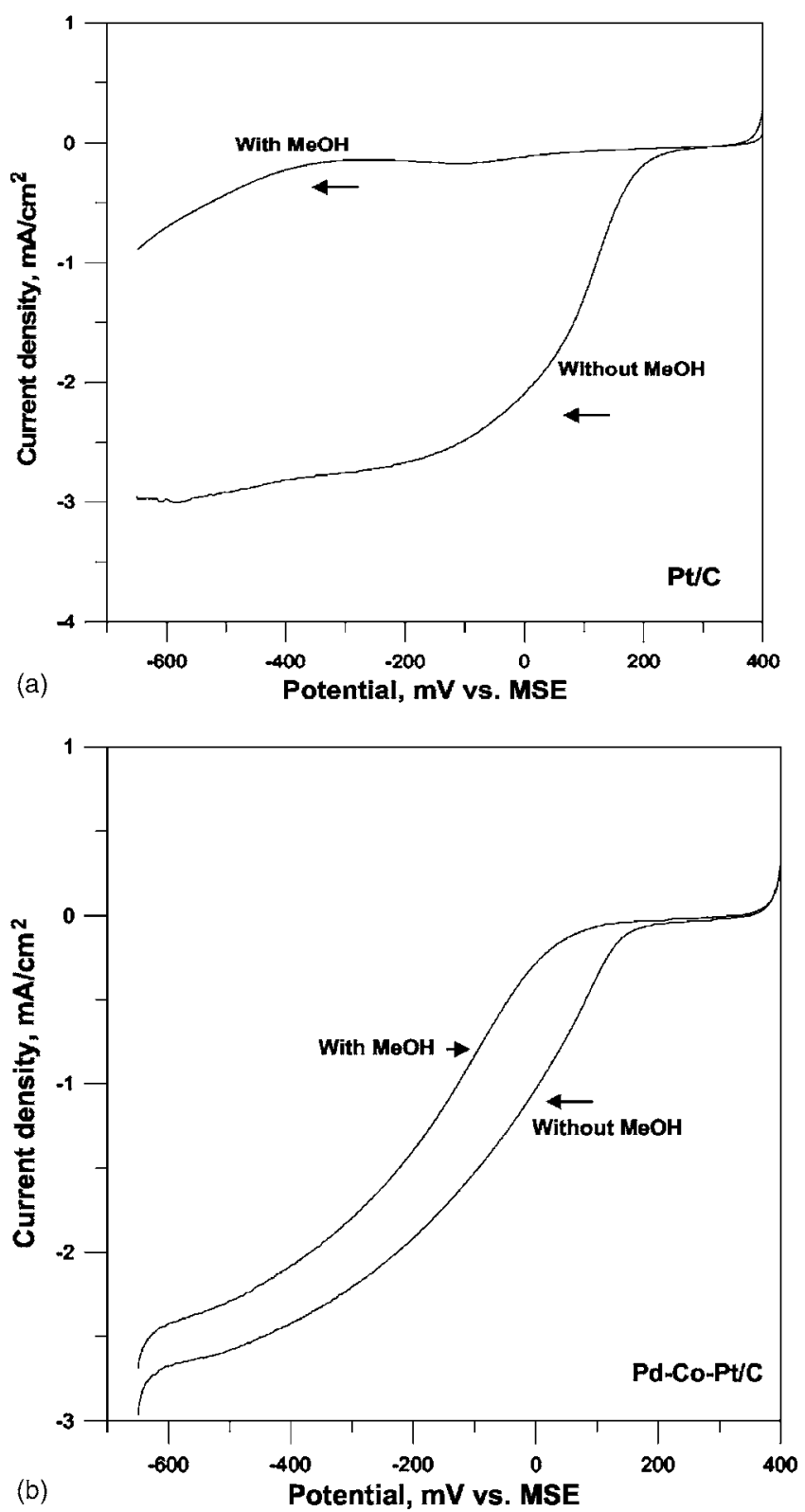

Figure 6. Comparison of polarization curves for ORR on (a) $\mathrm{Pt} / \mathrm{C}$ and (b) $\mathrm{Pd}-\mathrm{Co}-\mathrm{Pt}$ in $0.1 \mathrm{M} \mathrm{H}_{2} \mathrm{SO}_{4}$ with and without $0.1 \mathrm{M}$ methanol $1600 \mathrm{rpm}$ scan rate $5 \mathrm{mV} / \mathrm{s}$.

\section{Conclusion}

The $\mathrm{Pd}-\mathrm{Co}-\mathrm{M}(\mathrm{M}=\mathrm{Pt}, \mathrm{Au}, \mathrm{Ag})$ catalysts are prepared through reverse microemulsion method and characterized using XRD and TEM. The average particle size was found to be $20 \mathrm{~nm}$ for the untreated catalyst materials. The ORR kinetics of the catalyst materials was analyzed using the rotating ring disk electrode (RRDE) technique. Koutecky-Levich analysis of the voltametric data for different electrodes showed the reaction to follow a first-order reaction with respect to the diffusing reactant. The experimental value of the $\mathrm{K}-\mathrm{L}$ slope agrees with the one calculated assuming a $4 \mathrm{e}$ charge transfer in the oxygen reduction. The amount of peroxide formation estimated from the RRDE measurements was found to be $1.1 \%$ that is considered to be negligible. Among the materials studied here, $\mathrm{Pd}-\mathrm{Co}-\mathrm{Pt}$ alone showed a high methanol tolerance and ORR activity, despite a cathodic shift of $\sim 110 \mathrm{mV}$. 


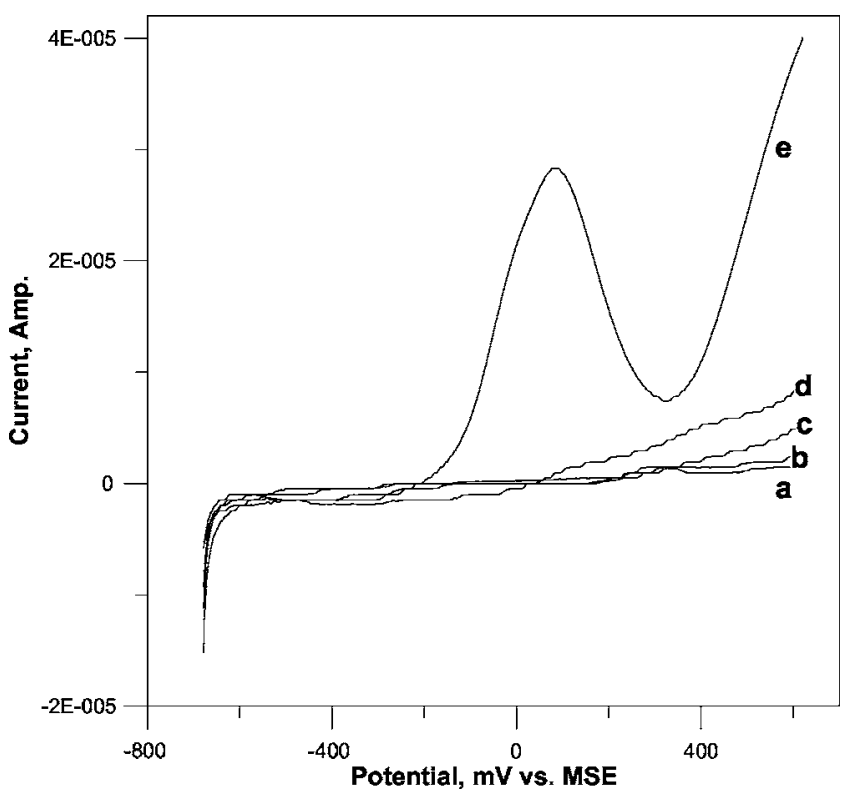

Figure 7. Comparison of polarization curves for methanol oxidation on carbon supported (a) $\mathrm{Pd}-\mathrm{Co}-\mathrm{Ag} / \mathrm{C}$, (b) $\mathrm{Pd}-\mathrm{Co} / \mathrm{C}$, (c) $\mathrm{Pd}-\mathrm{Co}-\mathrm{Au} / \mathrm{C}$, (d) $\mathrm{Pd}-\mathrm{Co}-\mathrm{Pt} / \mathrm{C}$ an, (e) $\mathrm{Pt} / \mathrm{C}$ alloy catalyst in $0.5 \mathrm{M}$ sulfuric acid $+0.5 \mathrm{M}$ methanol solution purged with high pure nitrogen gas, scan rate $5 \mathrm{mV} / \mathrm{s}$; room temperature $25^{\circ} \mathrm{C}$

\section{Acknowledgments}

The authors thank the Department of Science and Technology, New Delhi, for financial assistance (SR/S1/PC-37/2004), Dr. B. Sreedhar, Indian Institute of Chemical Technology, Hyderabad, for TEM measurements and Professor A. K. Shukla, Director, CECRI, for his encouragement.

Central Electrochemical Research Institute assisted in meeting the publication costs of this article.

\section{References}

1. L. Carrette, K. A. Friedrich, and U. Stimming, ChemPhysChem, 1, 162 (2000).

2. X. Ren, M. S. Wilson, and S. Gottesfeld, J. Electrochem. Soc., 143, L12 (1996)

3. K. Ravikumar and A. K. Shukla, J. Electrochem. Soc., 143, 2601 (1996).

4. P. S. Kauranen and E. Skou, J. Electroanal. Chem., 408, 189 (1996).

5. B. Gurau and E. S. Smotkin, J. Power Sources, 112, 339 (2002).

6. P. M. Urban, A. Funke, J. T. Muller, M. Himmen, and A. Docter, Appl. Catal., A, 221, 459 (2001).

7. A. Heinzel and V. M. Barragan, J. Power Sources, 84, 70 (1999).

8. K. Ramya and K. S. Dhathathreyan, J. Electroanal. Chem., 542, 109 (2003).
9. J. Cruickshank and K. Scott, J. Power Sources, 70, 40 (1998).

10. A. K. Shukla, R. K. Raman, N. A. Choudhury, K. R. Priolkar, P. R. Sarode, S. Emura, and R. Kumashiro, J. Electroanal. Chem., 563, 181 (2004).

11. W. Yuan, K. Scott, and H. Cheng, J. Power Sources, 163, 323 (2006).

12. M. T. Paffett, J. G. Beery, and S. Gottesfeld, J. Electrochem. Soc., 135, 1431 (1988).

13. J. R. C. Salgado, E. Antolinia, and E. R. Gonzalez, Appl. Catal., B, 57, 283 (2005).

14. B. C. Beard and P. N. Ross, J. Electrochem. Soc., 137, 3368 (1990).

15. T. Toda, H. Igarashi, and M. Watanabe, J. Electroanal. Chem., 460, 258 (1999).

16. N. Neergat, A. Shukla, and K. S. Gandhi, J. Appl. Electrochem., 31, 373 (2001).

17. R. C. Koffi, C. Coutanceau, E. Garnier, J.-M. Leger, and C. Lamy, Electrochim Acta, 50, 4117 (2005).

18. H. Yang, C. Coutanceau, J.-M. Leger, N. A.-Vante, and C. Lamy, J. Electroanal. Chem., 576, 305 (2005)

19. N. K. Beck, B. Steiger, G. G. Scherer, and A. Wokaun, Fuel Cells, 6, 26 (2006).

20. D. Xia, G. Chen, Z. Wang, J. Zhang, S. Hui, D. Ghosh, and H. Wang, Chem Mater, 18, 5746 (2006).

21. C. Roychowdhury, F. Matsumoto, V. B. Zeldovich, S. C. Warren, P. F. Mutolo, M. Ballesteros, U. Wiesner, H. D. Abruna, and F. J. DiSalvo, Chem. Mater, 18, 3365 (2006).

22. H. Yang, N. Alonso-Vante, J.-M. Leger, and C. Lamy, J. Phys. Chem. B, 108, 1938 (2004).

23. S. Baranton, C. Coutanceau, C. Roux, F. Hahn, and J.-M. Leger, J. Electroanal. Chem., 577, 223 (2005).

24. Y. Lu and R. G. Reddy, Electrochim. Acta, 52, 2562 (2007).

25. D. Chu and R. Jiang, Solid State Ionics, 148, 591 (2002).

26. X. Wang, M. Waje, and Y. Yan, J. Electrochem. Soc., 151, A2183 (2004).

27. R. W. Reeve, P. A. Christensen, A. Hamnett, S. A. Haydock, and S. C. Roy, $J$ Electrochem. Soc., 145, 3463 (1998).

28. T. J. Schmidt, U. A. Paulus, H. A. Gasteiger, N. Alonso-Vante, and R. J. Behm, J. Electrochem. Soc., 147, 2620 (2000).

29. S. S. Ozenler and F. Kadirgan, J. Power Sources, 154, 364 (2006).

30. J. L. Fernandez, D. A. Walsh, and A. J. Bard, J. Am. Chem. Soc., 127, 357 (2005).

31. O. Savadogo, K. Lee, K. Oishi, S. Mitsushima, N. Kamiya, and K.-I. Ota, Electrochem. Commun., 6, 105 (2004).

32. K. Lee, O. Savadogo, A. Ishihara, S. Mitsushima, N. Kamiya, and K.-I. Ota, J. Electrochem. Soc., 153, A20 (2006).

33. M.-H. Shao, K. Sasaki, and R. R. Adzic, J. Am. Chem. Soc., 128, 3526 (2006).

34. V. Raghuveer, A. Manthiram, and A. J. Bard, J. Phys. Chem. B, 109, 22909 (2005).

35. V. Raghuveer, P. J. Ferreira, and A. Manthiram, Electrochem. Commun., 8, 807 (2006).

36. J. L. Fernandez, V. Raghuveer, A. Manthiram, and A. J. Bard, J. Am. Chem. Soc., 127, 13100 (2006)

37. Low Pt Loading Fuel Cell Electrocatalysts, DOE Hydrogen Program FY Progress Report, pp. 828-832 (2005).

38. W. Wang, D. Zheng, C. Du, Z. Zou, X. Zhang, B. Xia, H. Yang, and D. L. Akins, J. Power Sources, 167, 243 (2007).

39. L. Zhang, K. Lee, and J. Zhang, Electrochim. Acta, 52, 3088 (2007).

40. W. E. Mustain, K. Kepler, and J. Prakash, Electrochem. Commun., 8, 406 (2006)

41. M. R. Tarasevich, A. E. Chalykh, V. A. Bogdanovskaya, L. N. Kuznetsova, N. A. Kapustina, B. N. Efremov, M. R. Ehrenburg, and L. A. Reznikova, Electrochim. Acta, 51, 4455 (2006)

42. M. H. Shao, T. Huang, P. Liu, J. Zhang, K. Sasaki, M. B. Vukmirovic, and R. R. Adzic, Langmuir, 22, 10409 (2006)

43. J. Zhang, Y. Mo, M. B. Vukmirovic, R. Klie, K. Sasaki, and R. R. Adzic, J. Phys. Chem. B, 108, 10955 (2004)

44. J. Zhang, F. H. B. Lima, M. H. Shao, K. Sasaki, J. X. Wang, J. Hanson, and R. R. Adzic, J. Phys. Chem. B, 109, 22701 (2005).

45. Y. Wang and P. B. Balbuena, J. Phys. Chem. B, 109, 18902 (2005). 